\title{
Low Genetic Diversity in Turkish Populations of Wels Catfish Silurus glanis L., 1758 (Siluridae, Pisces) Revealed by Mitochondrial Control Region Sequences
}

\author{
Yusuf Bektaş $^{1, *}$ (D), Ismail Aksu², Gokhan Kalayci², Davut Turan² \\ ${ }^{1}$ Department of Biology, Faculty of Arts and Sciences, Recep Tayyip Erdogan University, 53100, Rize, Turkey. \\ ${ }^{2}$ Department of Basic Sciences, Faculty of Fisheries, Recep Tayyip Erdogan University, 53100, Rize, Turkey.
}

\section{Article History}

Received May 5, 2020

Accepted September 9, 2020

First Online September 10, 2020

\section{Corresponding Author}

Tel.: +904642234093

E-mail: yusuf.bektas@erdogan.edu.tr

\section{Keywords}

D-loop (Control Region)

Turkey

Population Genetics

Wels catfish

\begin{abstract}
This study aimed to investigate the genetic diversity and population structure of Wels catfish Silurus glanis L. 1758 in Turkey using squences of the mitochondrial DNA control region The 887-bp fragment of $D$-loop was aligned for $112 \mathrm{~S}$. glanis individuals from ten wild populations in Turkey, defined by 29 polymorphic sites comprising 16 haplotypes. The low haplotype diversity and nucleotide diversity within each population ranged from 0.000 to 0.378 and from 0.0000 to 0.0045 , respectively. Analysis of molecular variance showed significant genetic differentiation among ten populations $\left(F_{S T}=0.940 ; \mathrm{P}<0.01\right)$. AMOVA revealed that the most of genetic variation was found between Thrace and Anatolia clades (74,07\%). The phylogenetic trees and haplotype network topologies were consistent with the results of AMOVA analysis. The non-significant negative Tajima's $D(-0.875 \mathrm{P}<0.05)$ and Fu's Fs $(-0.381, \mathrm{P}<0.02)$ values and mismatch distribution for $S$. glanis populations indicated no evidence for changes in population size. Furthermore, goodness-of-fit of the observed versus the theoretical mismatch distribution tested the sum of squared deviation (SSD; 0.00308, P>0.05), Harpending's raggedness index (Hri; $0,300, P>0.05$ ) and Ramos-Onsins \& Rozas (R2; $0,0771, \mathrm{P}>0.05)$, supporting population neutrality.
\end{abstract}

\section{Introduction}

The family Siluridae contains 12 genera and about 100 species (CABI, 2020). The genus Silurus has 21 species (Fricke et al., 2020), of which one is native to Euriasia: the wels catfish (Silurus glanis). The wels catfish, Silurus glanis (Linnaeus, 1758), is one of the largest and the economically important freshwater fish species belonging to the family Siluridae, which is widely distributed throughout Eurasia (Alp et al., 2011; Bănărescu, 1989; Geldiay \& Balık, 2007; Kottelat \& Freyhof, 2007; Krieg et al., 2000) including Turkey. Although the large size suggests high potential for dispersion, it suggests that natural distribution is slow and density dependent (Copp et al., 2009). Silurus glanis is found in all inland waters of Turkey except for the Tigris and Euphrates River Basins (Çelikkale, 1994; Geldiay \& Balık, 1988). Despite the increasing economic importance of S. glanis in aquaculture (Alp et al., 2011; Arteni, 2009; Copp et al., 2009; Doğan Bora \& Gül, 2004; Linhart et al., 2002; Muscalu et al., 2010) and the recent stocking and fish farming activities in Turkey (Saygı \& Güleç, 2019; Republic of Turkey Ministry of Agriculture and Forestry, Mediterranean Fisheries Research, Production and Training Institute, 2019), little is known about the genetic structure of cultivated or wild wels catfish stocks in Turkey. S. glanis is listed as Least Concern (LC) in the IUCN Red List of Threatened Species 
(http://www.iucnredlist.org/). However, the ecology of its wild populations is not well known, probably due to the difficulty of sampling such a large species in large rivers or lentic ecosystems (Alp et al., 2011; Carol et al., 2007; Carol et al., 2009; Copp et al., 2009).

Mitochondrial DNA analysis has proved to be useful for studying population structure and genetic diversity in many animal species (Avise, 1994). The control region (CR), a non-protein-coding region, containing the replication origin of mitochondrial DNA, has been frequently used to reveal population structuring in fish; because: 1) it is not affected by selective pressure because it does not encode any protein, and it accumulates mutations faster than other genomic regions (Kumar et al., 2012, Kumar et al., 2014; Parmaksiz, 2020; Xiao et al., 2009; Xue et al., 2020). To date, the population structure and genetic diversity of some catfishes such as Amur catfish (Xue et al., 2020), Asian catfish (Khedkar et al., 2016), African catfish (Barasa et al., 2016), the silver catfish (Nwafili \& Gao, 2016), yellow catfish (Zhong et al., 2013), neotropical catfish (Paixão et al., 2018) and Mekong giant catfish (Phadphon et al., 2019) were investigated by mitochondrial DNA control region. Populations covering of the whole range of $S$. glanis was investigated using PCR-RFLP analysis of four mitochondrial DNA regions, including the control region (Krieg et al., 2000). Although there is a significant mitochondrial differentiation among the populations, a consistent geographic structuring model did not reveal and the nucleotide divergence among the $S$. glanis populations were low. Triantafyllidis et al. (2002) investigated the genetic structure of the natural distribution of S. glanis using SSR markers and found that levels of genetic diversity were much higher than in previous RFLP mitochondrial DNA analyzes. Despite the large genetic differentiation of the S. glanis populations, a consistent geographical structuring model has not emerged, unlike previous studies of European freshwater fish species. A pattern isolation by distance seems more likely, and the final distribution hypothesis has been proposed from only one glacial refugium around the Ponto-Caspian region. The genetic diversity and genetic structure of S. glanis populations in the northwestern Iran were evaluated using ISSR markers by Kamangar and Rostamzadeh (2015). The analysis of molecular variance results revealed significant differences between geographic regions in Iran. Palm et al. (2019) investigated the genetic structure of Swedish's European wels catfish populations using polymorphic microsatellite loci for a large sample group. Compared to data from a previous study of populations in other parts of Europe, they identified a relatively low-level effective population size and genetic diversity for Swedish populations. In line with the previous proposal of postglacial colonisation from a single refugium, it was reported that all Swedish populations were gathered on a common branch in a star-shaped dendrogram together with other European populations. On the other hand, It was indicated that even minor dispersal barriers may restrict gene flow for wels in running waters. The genetic assignment of specimens encountered in the brackish Baltic Sea and in lakes where the species did not occur naturally showed the presence of long-distance sea dispersal and illegal translocations. So far, the genetic structure of European (Krieg et al., 2000; Triantafyllidis, Ozouf-Costaz et al., 1999; Vittas et al., 2011) and Iranian (Kamangar \& Rostamzadeh, 2015) S. glanis populations were investigated using few mitochondrial or nuclear markers. However, currently, there is only one report about the genetic diversity, phylogenetic relationship and population genetic structure of wels catfish in Turkey.

Studying genetic diversity and population structure is essential for conservation of wels catfish, which depends on the knowledge of the amount of variation existing in natural populations. Therefore, this approach requires determining evolutionary units for wels catfish conservation and sustainable use. The purpose of this study is to uncover the population genetic structure of S. glanis using the control region of mitochondrial DNA (887 bp) from ten localities in Turkey.

\section{Material and Methods}

\section{Sample Collections and DNA Extraction}

Major river systems representing the natural distribution of Wels catfish in Turkey was chosen as sampling sites. A total of 112 catfish specimens were sampled by traps or trawls from commercial fishermen in ten populations of $S$. glanis throughout Turkey (Figure 1, Table 3). Fish sampling was performed by using multifilament trammel nets with between 20 and 140 $\mathrm{mm}$ streched mesh sizes. However, baited pelagic longline with different mouth opening sized hooks and fyke nets were used in fish samplings. Fishing operations was performed at depths varied from 2 to $30 \mathrm{~m}$. Operational plans relating to fishing grounds for the trials were based on the prior experience of fishermen in the region. The number of samples taken for each location is given in Table 3. Fin-clips were immediately preserved in $95 \%$ ethanol and stored at $4^{\circ} \mathrm{C}$ until processed. Whole genomic DNA was extracted using Wizard Genomic DNA Purification kit (Promega Corporation, Madison, WI, U.S.A.) according to the manufacturer's protocol, followed by measuring the quality and quantity of total DNA using Nanodrop 2000C spectrophotometer (Thermo Fisher Scientific, Wilmington, DE, USA), and subsequently its quality was checked by agarose gel electrophoresis. Extracted DNA was kept frozen at $-20^{\circ} \mathrm{C}$ until gene amplification.

\section{PCR Amplification and Sequencing of Control Region}

The mitochondrial CR primers (SGDF: 5GCGCCGGTCTTGTAATCCGG-3 and SGDR: 5TAGTAAAGTCAGGACCAAGCC-3) were designed from 
similar sequences determined by the BLAST search on the National Center for Biotechnology Information (NCBI, http://www.ncbi.nlm.nih.gov/) using the Primer3Plus interface (http://frodo.wi.mit.edu/). The mtDNA CR were amplified via polymerase chain reaction (PCR) in a $50 \mu \mathrm{l}$ reaction volume with $10 \mu \mathrm{l}$ of $5 \mathrm{x}$ Taq polymerase buffer (Promega), $4 \mu \mathrm{l}$ of $10 \mathrm{mM}$ each dNTP, $4 \mu \mathrm{l}$ of $25 \mathrm{mM} \mathrm{MgCl}_{2}, 1 \mu \mathrm{l}$ of $10 \mathrm{pmol}$ of each primer, 0.2 $\mu \mathrm{l}$ Taq DNA polymerase $(1 \mathrm{U} / \mu \mathrm{l}$; Promega Corp., Madison, WI), $26.8 \mu$ listilled water and $3 \mu$ template DNA $(20 \mathrm{ng} / \mu \mathrm{l}$ ) using T-100 Thermal Cyclers (Bio-Rad Laboratories Inc, USA). PCR cycling conditions consisted of an initial denaturation step at 94 o $C$ for $3 \mathrm{~min}, 35$ cycles of 94 으 for $45 \mathrm{sec}$, 53으 for $45 \mathrm{sec}$ and 72 으 for $1 \mathrm{~min}$, followed by a final extension of $7 \mathrm{~min}$ at $72^{\circ} \mathrm{C}$ and a 4 으 hold. PCR products were visualized on $\mathrm{EtBr}$ stained $1.2 \%$ agarose gel electrophoresis. PCR products were purified using ethanol precipitation and the purified PCR products were directly sequenced in both directions using PCR primers on an $A B I$ 3730XL DNA Analyzer (Applied Biosystems) by Macrogen Inc. (Amsterdam, The Netherlands).

\section{Data Analysis}

Nucleotide sequences of the mitochondrial control region $(C R)$ were trimmed and assembled using Seqman version 7 (Lasergene; DNASTAR). Multiple sequence alignments were created using Clustal W (Thompson et al., 1994) as implemented in MEGA version X (Kumar et al., 2018). The number of haplotype (h), haplotype diversity $(\mathrm{Hd})$ and nucleotide diversity $(\pi)$ were computed in DnaSP version 5.10.01 (Librado \& Rozas, 2009) and Arlequin v 3.5 (Excoffier \& Lischer, 2010).

To visualize the relationships among haplotypes, a haplotype network was constructed using the median joining (MJ) algoritm (Bandelt et al., 1999) as implemented in the software PopART 5.0.1.1 (Leigh \& Bryant, 2015). Phylogenetic inference analyses were conducted using Maximum Likelihood (ML) and Bayesian Inference (BI) methods. The most suitable model of nucleotide substitution was calculated by the Akaike Information Criteria (AIC) and Bayesian Information Criteria (BIC) approaches in the program jModeltest 2.1.1 (Darriba et al., 2012). Maximum likelihood analysis was performed using the $\mathrm{HKY}+\mathrm{G}$ model the programs GARLI v.2.0 (Zwickl, 2006) with 10 random sequence addition replicates, tree bisection reconnection (TBR) branch swapping with 500 replicates using PhyML 3.0 (Guindon \& Gascuel, 2003). The Bayesian analysis was conducted with MrBayes v3.2 (Ronquist et al., 2012) with the $\mathrm{HKY}+\mathrm{G}$ model determined with jmodelTest 0.1.1 (Posada, 2008). The four-indepentend MCMC (Markov Chain Monte Carlo) analyses were run simultaneously for 2 million generations, with sampling every 1000 generations. The first $25 \%$ of generations were discarded as "burn in". Lake Kastoria haplotypes (Genbank no: AM398435 and AM113592) from the Northern Greece, which represent to Europe, were used as comparison material in phylogenetic analysis. Trees were rooted using CR sequences of Mesopotamian catfish $S$. triostegus Heckel, 1843 (GenBank accession number MT183652MT183656) were visualized using the MEGA X program.

Hierarchical analysis of molecular variance (AMOVA) with 10,000 permutations was performed to test the population genetic structure of $S$. glanis in Turkey. To quantify the genetic divergence, we computed pairwise $F_{S T}$ (fixation index) values between populations with 10,000 permutations. AMOVA, and $F_{S T}$ were all calculated using the software Arlequin v3.5.2.2 (Excoffier \& Lischer, 2010).

\section{Demographic History}

We performed the neutrality tests Fu's Fs (Fu, 1997) and Tajima's D (Tajima, 1989), implemented in the program Arlequin version 3.5 (Excoffier \& Lischer, 2010)

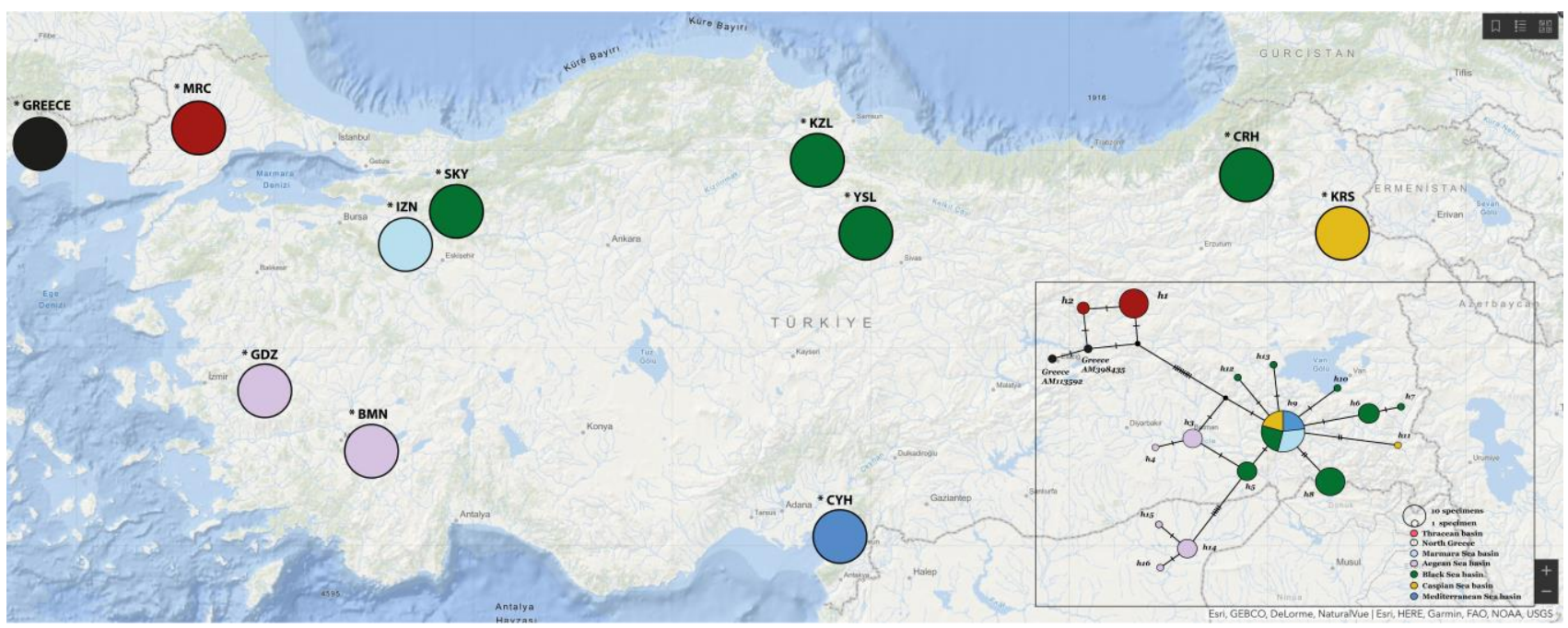

Figure 1. Map of Turkey indicating the sampling locations of the wels catfish populations included in the study. Median- Joining haplotype network of S. glanis CR haplotypes from Turkey. The size of circles are relative to the frequency of the haplotype. A branch represents a single nucleotide change. 
to infer the demographic history of wels. Significance of these tests ( $p$ values) was calculated by developing 1000 simulations. The historical demographic events were also investigated with the mismatch distribution analysis using the program Arlequin v 3.5 (Excoffier \& Lischer, 2010). The validity of the estimated demographic model was tested using the sum of squared deviations (SSD) of observed and expected mismatch (Rogers \& Harpending, 1992) with a parametric bootstrapping approach using 10,000 replicates. Deviations from the estimated demographic model were evaluated using the tests of Harpending's raggedness index (Hri), (Harpending, 1994) and the R2 statistic (Ramos-Onsins \& Rozas, 2002) in program DnaSP (Librado \& Rozas, 2009).

\section{Results and Discussion}

\section{Genetic Diversity}

A total of 112 specimens of $S$. glanis were sequenced for the mitochondrial CR (887 bp). The nucleotide content averaged $24.2 \%$ C, 31.3\% T, 30.0\% A, and $14.5 \% \mathrm{G}$. The $D$-loop was $61.4 \% \mathrm{~A}+\mathrm{T}$ rich, which is consistent with the bias reported in other vertebrates (Alvarado Bremer et al., 1997). In 112 specimens, the aligned sequences exhibited 29 variable sites (127 singleton variable sites, 17 parsimony informative sites, and 26 insertions/deletions). Overall, 16 different haplotypes were identified (GenBank accession numbers MT183636- MT183651, Table S1). Their distribution and relative frequencies by population are shown in Table S2. Eigth (50.0\%) of these haplotypes occurred just once, one were shared by only two individuals, whereas the haplotypes 1, 3, 5, 6 and 14 were found in eigth or more individuals. Haplotypes 8 and 9, which were the most common haplotypes, were observed in two (CRH and YSL) and four populations (IZN, CYH, KRS and SKY), respectively. Generally, wels catfish samples displayed heterogeneity in haplotype frequencies (Table 2). However, the numerous populations in Anatolia (SKY, IZN, KRS, YSL, CRH and $\mathrm{CYH}$ ) shared haplotypes 8 and 9 (Table S2), which implies that the presence of the newly isolated populations in Turkey. It is moreover known that the distribution and evolution of several species in Turkish freshwaters such as Rhodeus (Bektaş et al., 2013), Salmo (Bardakci et al., 2006) and Capoeta (Bektaş et al., 2011; Parmaksiz \& Eksi, 2017) were influenced by the last glacial periods in Eurasia.

Summary statistics including haplotype richness, haplotype diversity, and nucleotide diversity in each population are given in Table 2. Measures of haplotype and nucleotide diversity based on the $\mathrm{CR}$ sequences revealed that the haplotype $(H)$ and the nucleotide diversities $(\pi)$ within each population ranged from 0.000 to 0.378 and from 0.0000 to 0.0045 , respectively (Table 2). Previous studies reported a low level of genetic diversity using different genetic markers such as RFLP (from 0.00 to $0.52 \%$, Triantafyllidis, Abatzopoulos, et al., 1999) and mtDNA (from 0.00 to $0.91 \%$, Krieg et al., 2000) in S. glanis populations from Europe and Middle East. On the other hand, the present study of mtDNA variation in Turkish S. glanis populations indicated low levels of diversity but high differentiation among these populations similar to that of $S$. glanis populations in Greece (Triantafyllidis, Abatzopoulos, et al., 1999) and Europe (Krieg et al., 2000). In contrast to the results of Krieg et al. (2000) and Triantafyllidis et al. (2002), there is a remarkable genetic distance of $1.3 \pm 0.31 \%$ between the Thracean and Anatolian populations in Turkey. Although the Black Sea, which is considered as one of the most important refugies that freshwater fish colonize Anatolia and Europe (Bernatchez, 2001; Durand et al., 1999; Kotlík et al., 2004; Kotlík et al., 2008; Triantafyllidis et al., 2002), is thought to promote the diversification of freshwater fish lineages, apex predators with high tolerance to the environmental conditions such as catfish may exhibit a lower level of genetic diversity.

\section{Genetic Relationships}

The genetic associations among 16 CR haplotypes identified in eleven populations of $S$. glanis, most of which are separated by a mutational step, are illustrated by the Median joining network (MJ; Figure 1). Topology of the haplotype network obtained from the $C R$ sequences showed a potent haplotypic structure with two distinct haplotype groups: Thracian (MRC) and Anatolian (the rest of all) separated by 8 mutational steps (Figure 1). Phylogenetic relationships are represented by $\mathrm{ML}$ and Bayesian trees of 16 haplotypes of S. glanis (Figure 2). The topology of $\mathrm{ML}$ and $\mathrm{BI}$ trees was congruent (Figure 1, 2). The analyses produced highly concordant trees, each revealing that $S$. glanis forms a monophyletic lineage with respect to the two clades (Thrace and Anatolia). In the phylogenetic trees (Figure 2), all haplotypes grouped into two main groups (Thrace: MRZ, and Anatolia: BMN, IZN, SKY, KZL, YSL; $\mathrm{SYH}, \mathrm{CRH}, \mathrm{KRS}$ and GDZ) with high values of posterior probabilities or bootstrap values (Figure 2). In the Anatolian clade, two subclades were seen consisting of Eastern and Western Turkish populations. The phylogenetic tree and haplotype network generally do not show a significant relationship between genetic distance and geography in Turkish populations, while there is a grouping tendency for wels catfish populations in the European (Thrace) and Asian (Anatolia) parts of Turkey. Based on the phylogenetic tree and haplotype network, the population structure of $S$. glanis, detected with two major clades, were observed in the some freshwater species in Turkey such as killifish (Triantafyllidis et al., 2007), salmon (Bardakci et al., 2006; Bernatchez, 2001), narrow-clawed crayfish (Akhan et al., 2014), and fire-bellied toad (AlpagutKeskin et al., 2010). These two continental clades, "Europe" and "Asia" suggest a prevalence of intra- 


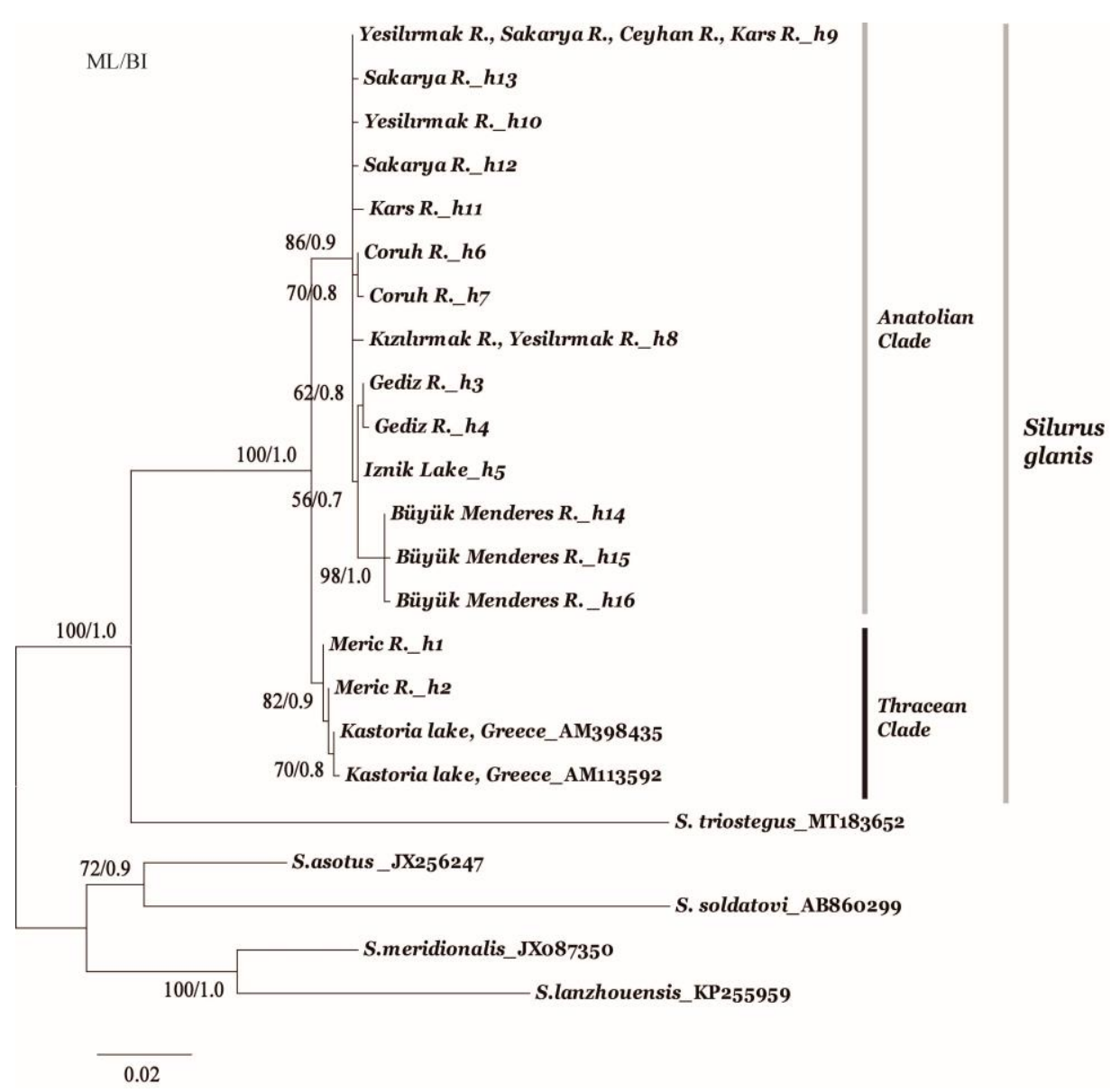

Figure 2. Phylogenetic relationships within S. glanis obtained from ML analysis of mtDNA CR sequences. Support values given as MP bootstrap/ML bootstrap/posterior probability: only support values above 50 are shown.

continental diversification of catfishes. Thus, the $C R$ phylogeny identifies the well-known European-Asian relationships within catfishes (Sullivan et al., 2006).

\section{Demographic Neutrality and Population Genetic Structure}

Demographic analysis was carried out in ten populations. Non-significant negative Fu's Fs (Fs = 0.381; $P<0.02)$ and Tajima's $D$ test $(D=-0.875 ; P<0.05)$ values were detected in all populations except for IZN, KZL and CYH populations, indicating Tajima's D and Fu's Fs test were centered at zero (Table 2), which represents neutrality. The results of the mismatch distribution for Turkish Wels catfish populations (Figure 3) showed a tendency to multimodal and ragged shape, revealing demographic equilibrium (Ray et al., 2003). The nonsignificant values for the neutrality tests indicate that the polymorphism occurring is coincident and is not under pressure. Both sum of squared deviation (SSD = $0.0030, p=0.092$, Table 2) and Harpending's raggedness index $(H r i=0.030, p=0.595$, Table 2$)$ values were significant in all populations ( $p$ value $>0.05$ ), confirming demographic stability of all population. In addition, the Ramos-Onsins and Rozas's R2 tests were not significant in populations ( $p$ value $<0.05$ ), rejecting demographic expansion ( $R 2=0.077, p=0.013$, Table 2 ). Overall, the multimodal mismatch distribution, non-significant negative neutrality index, genetic diversity values and the occurrence of only a few shared haplotypes among the populations showed evidence for demographic equilibrium in wels catfish located in present river systems in Turkey.

$F_{\text {ST }}$ value, which is a measure of population differentiation, was calculated for all populations. The values of pairwise $F_{S T}$ of eleven pairs of populations ranged from 0.008 (between $\mathrm{KRS}$ and $\mathrm{CYH}$ ) to 1.0000 (among KZL, IZN and $\mathrm{CYH}$ ), indicating high genetic differentiation among the populations except for a few population pairs (KZL and YSL, KRS and $\mathrm{CYH}, \mathrm{CYH}$ and SKY, KRS and SKY) and were statistically non-significant $(P \leq 0.05$, Table 1$)$. These results revealed statistically significant population differentiation $\left(F_{S T}=0.94052\right)$ throughout the range of S. glanis in Turkey (Table 3 ).

A hierarchical AMOVA was performed with the specimens divided into two "clades" Thrace and Anatolia populations of $S$. glanis. AMOVA analysis performed on the Turkish populations of $S$. glanis indicated that diversity among clades $\left(F_{\mathrm{CT}}=0.740\right.$; $\mathrm{P}<0.001$ ) explained $74.07 \%$ of the total molecular variance and $24.38 \%$ was explained by differences among populations within each groups $\left(F_{\mathrm{SC}}=0.9405\right.$; $\mathrm{P}<0.001)$, whereas only $1.54 \%$ of the variance was expressed within the populations $\left(F_{\mathrm{ST}}=0.984 ; \mathrm{P}<0.001\right)$. 


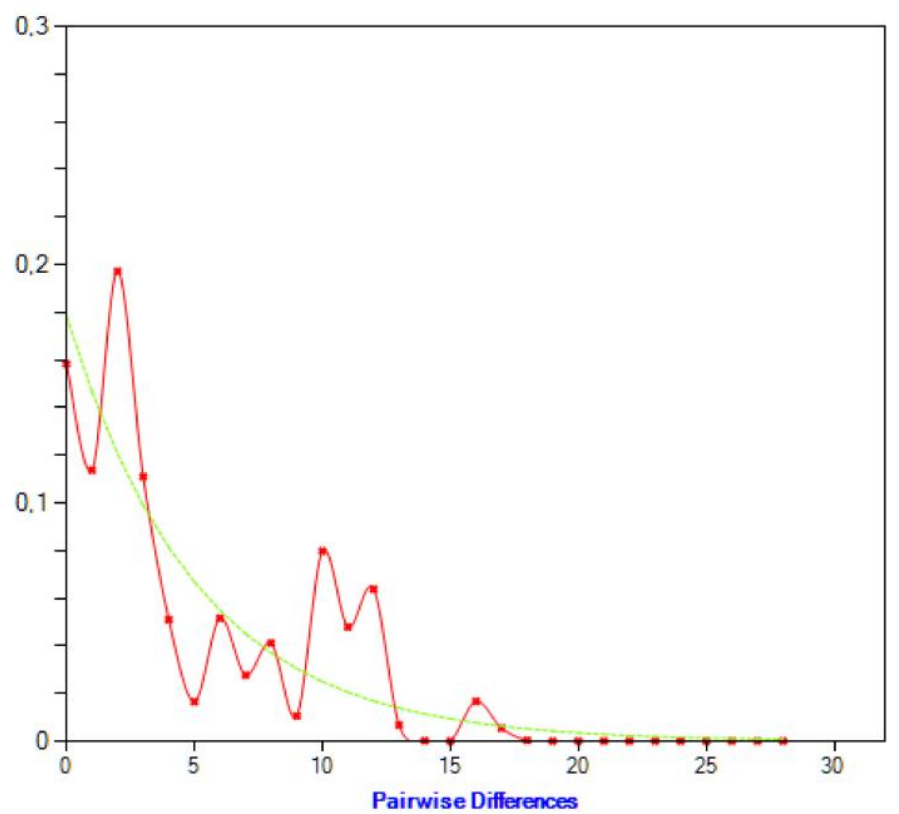

Figure 3. Mismatch distribution for CR haplotypes in S. glanis from 10 populations in Turkey under a model of population growth/decline model. The observed frequency is represented by a red line.

Table 1. Genetic distance between (upper diagonal) and within (diagonal) populations, and the fixation index considering genetic distances $\left(F_{\mathrm{ST}}\right)$ between populations (lower diagonal)

\begin{tabular}{lllllllllll}
\hline & MRC & GDZ & IZN & CRH & KZL & YSL & CYH & KRS & SKY & BMEN \\
\hline MRC & 0.016 & 1.168 & 1.277 & 1.289 & 1.396 & 1.402 & 1.159 & 1.181 & 1.183 & 1.900 \\
GDZ & 0.825 & 0.025 & 0.126 & 0.365 & 0.468 & 0.747 & 0.239 & 0.260 & 0.262 & 0.722 \\
IZN & 0.908 & 0.882 & 0.000 & 0.238 & 0.341 & 0.347 & 0.113 & 0.134 & 0.136 & 0.593 \\
CRH & 0.833 & 0.789 & 0.888 & 0.023 & 0.352 & 0.358 & 0.124 & 0.145 & 0.147 & 0.836 \\
KZL & 0.916 & 0.894 & 1.000 & 0.900 & 0.000 & 0.006 & 0.227 & 0.247 & 0.249 & 0.942 \\
YSL & 0.874 & 0.850 & 0.922 & 0.856 & 0.036 & 0.013 & 0.233 & 0.254 & 0.256 & 0.948 \\
CYH & 0.923 & 0.905 & 1.000 & 0.909 & 1.000 & 0.967 & 0.000 & 0.021 & 0.023 & 0.709 \\
KRS & 0.839 & 0.799 & 0.894 & 0.809 & 0.904 & 0.907 & 0.008 & 0.041 & 0.043 & 0.730 \\
SKY & 0.756 & 0.696 & 0.791 & 0.711 & 0.811 & 0.904 & 0.078 & 0.022 & 0.045 & 0.732 \\
BMEN & 0.756 & 0.696 & 0.791 & 0.711 & 0.811 & 0.974 & 0.827 & 0.724 & 0.622 & 0.045 \\
\hline
\end{tabular}

Notes: CRH: Coruh River, Artvin, KRS: Kars Stream, Kars, YSL: Yesilirmak River, Tokat, KZL: Kizilirmak River, Kırıkkale, SKY: Sakarya River, Sakarya, CYH: Ceyhan River, Adana, IZN: Iznik Lake, Bursa, GDZ: Gediz River, Manisa, BMN: Adıgüzel Lake, Güney, Uşak, MRC: Meric River, Edirne. Significance level ${ }^{n s} \mathrm{P} \leq 0.05$; * $\mathrm{P}>0.05$.

The significant fixation index Fst in most populations and low haplotype frequencies revealed the fixation of particular haplotypes in the majority of populations. The genetic variations between populations are an indication that there is a low gene flow between populations or that these populations are isolated. Herein, low haplotype frequencies indicate that populations have sufficient time to accumulate unique mutations. Because similar results were also obtained from other fishes such as Rhodeus (Bektaş et al., 2013), Salmo (Bardakci et al., 2006) and Capoeta (Bektaş et al., 2011; Parmaksiz \& Eksi, 2017) in region. The analysis of molecular variance reveals clear genetic difference between the Thracean and Anatolian populations of $S$. glanis in Turkey (Table 3), in contrast to previous studies of wels catfish (Krieg et al., 2000; Triantafyllidis et al., 2002). The AMOVA analysis previously conducted for catfish (Krieg et al., 2000) suggested that most of the genetic polymorphism (with 79\%) was due to differences between natural populations. This is similar when hatchery populations were included or taking into consideration only the populations that were analyzed in a previous allozyme study (Triantafyllidis, OzoufCostaz et al., 1999). In contrast to, the present study revealed that most of the molecular variance $(74 \%)$ is among the predicted groups. This can be explained by the fact that wels catfish populations from two different continents (Europe and Asia), separated by a marine barrier, were included in the study, unlike previous studies. Even though the notable genetic differentiation of $S$. glanis populations, no meaningful model of geographical structuring was revealed (Figure 2a, 2b), contrary to previous studies on the Anatolian freshwater fish species. This phenomenon could possibly be explained by the fact that $S$. glanis, which is very tolerant to environmental changes, may have reached present its 
Table 2. Statistical tests of neutrality and demographic parameter estimates with $P$-value (in parenthesis) for Silurus glanis populations. Population code $(\mathrm{Pc})$, sample size $(\mathrm{N})$, numbers of haplotypes $(\mathrm{h})$, haplotype diversity $\left(H_{d}\right)$, nucleotide diversity $(\pi)$, number of haplotypes (H), Tajima's D (D), Fu's (1997) Fs (Fs), sum of squares differences imn mistmach analysis (SSD), Harpending's (1994) raggedness index $\left(\mathrm{H}_{r i}\right)$, Ramos-Onsins and Rozas (R2) and GenBank Accession Numbers (GAN) are presented

\begin{tabular}{|c|c|c|c|c|c|c|c|c|c|c|}
\hline \multicolumn{5}{|c|}{ Diversity index } & \multicolumn{2}{|c|}{ Neutrality test } & \multicolumn{4}{|c|}{ Mistmatch distribution analysis } \\
\hline $\mathrm{Pc}$ & $\mathrm{N}$ & $\mathrm{h}$ & $H_{d}$ & $\pi$ & $\mathrm{D}$ & Fs & $\operatorname{SSD}(p)$ & $\mathrm{H}_{r i}(\mathrm{p})$ & $R_{2}$ & GAN \\
\hline $\mathrm{MRC}$ & 14 & h1-h2 & $0,143 \pm 0,119$ & $0,00016 \pm 0,00013$ & $-1,155^{N S}$ & $-0,594^{N S}$ & $0.00014 * *$ & $0,530 * *$ & $0,257^{\mathrm{NS}}$ & MT183636, MT183637 \\
\hline GDZ & 9 & h3-h4 & $0,222 \pm 0,166$ & $0,00025 \pm 0,00019$ & $-1,088^{N S}$ & $-0,263$ NS & $0.00046 * *$ & $0,358 * *$ & $0,314^{\mathrm{NS}}$ & MT183638, MT183639 \\
\hline IZN & 8 & h5 & $0,000 \pm 0,000$ & $0,00000 \pm 0,00000$ & 0,000 NS & 0.000 NS & $0.00000 \mathrm{NA}$ & $0.000 \mathrm{NA}$ & $0,000^{\mathrm{NS}}$ & MT183640 \\
\hline $\mathrm{CRH}$ & 10 & h6-h7 & $0,200 \pm 0,154$ & $0,00023 \pm 0,00017$ & $-1,111$ NS & $-0,339$ NS & $0.00041 * *$ & $0,400 * *$ & $0,300^{\mathrm{NS}}$ & MT183641, MT183642 \\
\hline KZL & 10 & h8 & $0,000 \pm 0,000$ & $0,00000 \pm 0,00000$ & 0,000 NS & 0.000 NS & $0.00000 \mathrm{NA}$ & $0.000 * *$ & $0,000^{\mathrm{NS}}$ & MT183643 \\
\hline YSL & 18 & h8-h10 & $0,111 \pm 0,096$ & $0,00013 \pm 0,00011$ & $-1,164$ NS & $-0,794$ NS & $0,00006 * *$ & $0,617 * *$ & $0,229^{N S}$ & MT183643-645 \\
\hline $\mathrm{CYH}$ & 12 & h9 & $0,000 \pm 0,000$ & $0,00000 \pm 0,00000$ & 0,000 NS & 0.000 NS & $0.00000 * *$ & $0.000 \mathrm{NA}$ & $0,000^{\mathrm{NS}}$ & MT183644 \\
\hline KRS & 11 & h9, h11 & $0,182 \pm 0,144$ & $0,00041 \pm 0,00032$ & $-1,429$ NS & 0,506 NS & $0,01810 * *$ & $0,735 * *$ & $0,287^{\mathrm{NS}}$ & MT183644, МT183646 \\
\hline SKY & 10 & h9, h12-13 & $0,378 \pm 0,181$ & $0,00045 \pm 0,00023$ & $-1,400 * *$ & $-1,164$ NS & $0.00580 * *$ & $0,182 * *$ & $0,200^{\mathrm{NS}}$ & MT183644, MT183647-648 \\
\hline \multirow[t]{2}{*}{ BMN } & 10 & h14-16 & $0,378 \pm 0,181$ & $0,00045 \pm 0,00023$ & $-1,400 * *$ & $-1,164^{\mathrm{NS}}$ & $0.00580 * *$ & $0,182 * *$ & $0,200^{\mathrm{NS}}$ & MT183649-651 \\
\hline & 112 & 16 & $0,842 \pm 0,018$ & $0,00519 \pm 0,00052$ & $-0,875 * *$ & $-0,381 \mathrm{NS}$ & $0.00308 * *$ & $0,030 * *$ & $0,077^{\mathrm{NS}}$ & \\
\hline
\end{tabular}

NANot avaliable; ${ }^{\text {NSN} N o n s i g n i f i c a n t, ~}{ }^{*} \mathrm{P}<0.02,{ }^{* *} \mathrm{P}<0.05 ;$; significant;

CRH: Coruh River, Artvin, KRS: Kars River, Kars, YSL: Yesilirmak River, Tokat, KZL: Kizilirmak River, Kırıkkale, SKY: Sakarya River, Sakarya, CYH: Ceyhan River, Adana, IZN: Iznik Lake, Bursa, GDZ: Gediz River, Manisa, BMN: Adıgüzel Lake, Uşak, MRC: Meric River, Edirne.

Table 3. Results of analysis of molecular variance (AMOVA) test on CR in different populations (Thrace and Anatolia) of Silurus glanis in Turkey

\begin{tabular}{|c|c|c|c|c|c|c|}
\hline Source of variation & d.f. & Sum of squares & Variance components & Percentage variation & \multicolumn{2}{|c|}{ Fixation Indices } \\
\hline Among groups & 2 & 124.122 & $4.27569 \mathrm{Va}$ & 74.07243 & $F_{\mathrm{CT}}$ & $0.74072^{* * *}$ \\
\hline Among populations within groups & 7 & 122.369 & $1.40760 \mathrm{Vb}$ & 24.38527 & $F_{\mathrm{sC}}$ & $0.98458^{* * *}$ \\
\hline Within populations & 102 & 9.080 & 0.08902 Vc & 1.54220 & $F_{\mathrm{ST}}$ & $0.94052^{* * *}$ \\
\hline Total & 111 & 255.571 & 4.85458 & & & \\
\hline
\end{tabular}

$F_{\mathrm{ST}}$ fixation index within populations; $F_{\mathrm{SC}}$ fixation index among populations within groups; $F_{\mathrm{CT}}$ fixation index between groups. ${ }^{* * *}<$ 0.001

geographical range through the late Pleistocene Black Sea (25-11.7 kya, Würm period) characterized by relatively low salinity levels in coastal areas (Copp et al., 2009; Froese \& Pauly, 2020).

\section{Conclusion}

Wels catfish in Turkey exhibit similarly low genetic diversity to those in Europe. This low genetic diversity might reflect the presence of a single Pleistocene glacial refugia in Black Sea, followed by postglacial expansion and subsequent genetic isolation. However, it has been determined that Thracian populations gradually diverge from the genetically remaining Anatolian populations. $S$. glanis, which is estimated to have spread to the region from the Pontic-Caspian basin, may have started to make different choices in its gene pool during the adaptation period to the habitats in which they settled. In order to support commercial fish stocks, the Republic of Turkey Ministry of Agriculture and Forestry, General Directorate of Agricultural Research and Policies (TEGEM) has been carrying out the fisheries project of Turkish inland waters since 2013. In this project, 20 thousand juveniles obtained from the industrial production of Gölhisar origin wels catfish are left to the Gölhisart lake (Burdur), Iznik lake (Bursa), Porsuk dam
(Kütahya), Kemer dam (Aydın) ve Hirfanlı dam (Ankara). Creating new stocks with hatchery breeding and release is an economically important strategy, but attention should be paid to maintaining the existence of genetic motifs in evolutionarily important units such as the Menderes, Iznik and Gediz populations.

\section{Acknowledgements}

This study was funded by Recep Tayyip Erdogan University Research Fund (Project No: 2009.103.01.2).

\section{References}

Akhan, S., Bektas, Y., Berber, S., \& Kalayci, G. (2014). Population structure and genetic analysis of narrowclawed crayfish (Astacus leptodactylus) populations in Turkey. Genetica, 142(5), 381-395. https://doi.org/10.1007/s10709-014-9782-5

Alp, A., Kara, C., Üçkardeş, F., Carol, J., \& García-Berthou, E. (2011). Age and growth of the European catfish (Silurus glanis) in a Turkish Reservoir and comparison with introduced populations. Reviews in Fish Biology and Fisheries, 21(2), 283-294.

https://doi.org/10.1007/s11160-010-9168-4

Alpagut-Keskin, N., Cevik, E. I., \& Arikan, H. (2010). Genetic Differentiation Among Peripheral Populations of 
Bombina bombina from Thrace and Anatolia: An Allozyme Analysis. Biochemical Genetics, 48(1), 125140. https://doi.org/10.1007/s10528-009-9305-8

Alvarado Bremer, J. R., Naseri, I., \& Ely, B. (1997). Othodox and unorthodox phylogenetic relationships among tunas revealed by the nucleotide sequence analysis of the mitochondrial DNA control region. Journal of Fish Biology, 50(3), 540-554.

https://doi.org/10.1006/jfbi.1996.0321

Arteni, M. O. (2009). Studies regarding some morphological features of one-summer old catfish (Silurus glanis Linnaeus, 1758). AACL Bioflux, 2(2), 217-222.

Avise, J. C. (1994). Molecular Markers, Natural History and Evolution. In Molecular Markers, Natural History and Evolution. https://doi.org/10.1007/978-1-4615-2381-9

Bănărescu, P. M. (1989). Zoogeography and history of the freshwater fish fauna of Europe. In J. Holcik (Ed.), The freshwater fishes of Europe (Vols I/II, pp. 88-107). Wiesbaden: AULA Verlag.

Bandelt, H. J., Forster, P., \& Röhl, A. (1999). Median-joining networks for inferring intraspecific phylogenies. Molecular Biology and Evolution, 16(1), 37-48. https://doi.org/10.1093/oxfordjournals.molbev.a02603 6

Barasa, J. E., Abila, R., Grobler, J. P., Agaba, M., Chemoiwa, E. J., \& Kaunda-Arara, B. (2016). High genetic diversity and population differentiation in Clarias gariepinus of Yala Swamp: evidence from mitochondrial DNA sequences. Journal of Fish Biology, 89(6), 2557-2570. https://doi.org/10.1111/jfb.13150

Bardakci, F., Degerli, N., Ozdemir, O., \& Basibuyuk, H. H. (2006). Phylogeography of the Turkish brown trout Salmo trutta L.: Mitochondrial DNA PCR-RFLP variation. Journal of Fish Biology, 68(SUPPL. 1), 36-55. https://doi.org/10.1111/j.0022-1112.2006.00948.x

Bektaş, Y., Beldüz, A. O., \& Turan, D. (2013). The phylogenetic position of turkish populations within the european bitterling, Rhodeus amarus (Osteichthyes: Cyprinidae). Zoology in the Middle East, 59(1), 39-50. https://doi.org/10.1080/09397140.2013.795063

Bektaş, Y., Çiftçi, Y., Eroğlu, O., \& Beldüz, A. O. (2011). Genetic discrimination of two Capoeta species in northeastern anatolia, using mitochondrial 16s Rrna gene: (Osteichthyes: Cyprinidae). Zoology in the Middle East, 53(1), 61-70.

https://doi.org/10.1080/09397140.2011.10648862

Bernatchez, L. (2001). The evolutionary history of brown trout (Salmo trutta L.) inferred from phylogeographic, nested clade, and mismatch analyses of mitochondrial DNA variation. Evolution, 55(2), 351-379. https://doi.org/10.1111/j.0014-3820.2001.tb01300.x

CABI, 2020. Invasive Species Compendium. Wallingford, UK: CAB International. Available at: https://www.cabi.org/isc/datasheet/64279.

Carol, J., Zamora, L., \& García-Berthou, E. (2007). Preliminary telemetry data on the movement patterns and habitat use of European catfish (Silurus glanis) in a reservoir of the River Ebro, Spain. Ecology of Freshwater Fish, 16(3), 450-456.

https://doi.org/10.1111/j.1600-0633.2007.00225.x

Carol, Joaquim, Benejam, L., Benito, J., \& García-Berthou, E. (2009). Growth and diet of European catfish (Silurus glanis) in early and late invasion stages. Fundamental and Applied Limnology, 174(4), 317-328. https://doi.org/10.1127/1863-9135/2009/0174-0317
Çelikkale, M. S. (1994). içssu Balıkları ve Yetiştiriciliği. Karadeniz Teknik Üniversitesi Sürmene Deniz Bilimleri Fakültesi.

Copp, G. H., Robert Britton, J., Cucherousset, J., GarcíaBerthou, E., Kirk, R., Peeler, E., \& Stakenas, S. (2009). Voracious invader or benign feline? A review of the environmental biology of European catfish Silurus glanis in its native and introduced ranges. Fish and Fisheries, 10(3), 252-282. https://doi.org/10.1111/j.14672979.2008.00321.x

Darriba, D., Taboada, G. L., Doallo, R., \& Posada, D. (2012). JModelTest 2: More models, new heuristics and parallel computing. Nature Methods, 9(8), 772. https://doi.org/10.1038/nmeth.2109

Doğan Bora, N., \& Gül, A. (2004). Feeding biology of Silurus glanis (L., 1758) living in Hirfanli Dam Lake. Turkish Journal of Veterinary and Animal Sciences, 28(3), 471479.

Durand, J. D., Persat, H., \& Bouvet, Y. (1999). Phylogeography and postglacial dispersion of the chub (Leuciscus cephalus) in Europe. Molecular Ecology, 8(6), 989-997. https://doi.org/10.1046/j.1365-294X.1999.00654.x

Excoffier, L., \& Lischer, H. E. L. (2010). Arlequin suite ver 3.5: A new series of programs to perform population genetics analyses under Linux and Windows. Molecular Ecology Resources, 10(3), 564-567. https://doi.org/10.1111/j.1755-0998.2010.02847.x

Fricke, R., Eschmeyer, W. N. \& van der Laan R. (2020). Eschmeyer's Catalog of Fishes: Genera, Species, References.

(http://researcharchive.calacademy.org/research/ichth yology/catalog/fishcatmain.asp).

Froese, R., \& Pauly, D. (2020). FishBase. 2020. World Wide Web Electronic Publication. http://www.fishbase.org.

$\mathrm{Fu}$, Y. X. (1997). Statistical tests of neutrality of mutations against population growth, hitchhiking and background selection. Genetics, 147(2), 915-925.

Geldiay, R., \& Balık, S. (1988). Türkiye Tatlısu Balıkları. Ege Üniversitesi Basımevi, Bornova, İzmir.

Geldiay, R., \& Balık, S. (2007). Türkiye Tatısu Balıkları (V. Baskı). Ege Üniversitesi Basımevi, Bornova, İzmir.

Guindon, S., \& Gascuel, O. (2003). A Simple, Fast, and Accurate Algorithm to Estimate Large Phylogenies by Maximum Likelihood. Systematic Biology, 52(5), 696-704. https://doi.org/10.1080/10635150390235520

Harpending, H. C. (1994). Signature of ancient population growth in a low-resolution mitochondrial DNA mismatch distribution. Human Biology, 66(4), 591-600.

Kamangar, B. B, \& Rostamzadeh, J. (2015). Genetic diversity and population genetic structure of Wels (Silurus glanis Linnaeus, 1758) in the northwest of Iran. Environmental Biology of Fishes, 98(8), 1927-1934. https://doi.org/10.1007/s10641-015-0411-7

Khedkar, G. D., Tiknaik, A., Kalyankar, A. D., A, C. S. R., Khedkar, C. D., Ron, T. B., \& Haymer, D. (2016). Genetic structure of populations and conservation issues relating to an endangered catfish, Clarias batrachus, in India. Mitochondrial DNA Part A, 27(2), 1181-1187. https://doi.org/10.3109/19401736.2014.945524

Kotlík, P., Bogutskaya, N. G., \& Ekmekçi, F. G. (2004). Circum Black Sea phylogeography of Barbus freshwater fishes: Divergence in the Pontic glacial refugium. Molecular Ecology, 13(1), 87-95. https://doi.org/10.1046/j.1365294X.2003.02021.x

Kotlík, P., Marková, S., Choleva, L., Bogutskaya, N. G., Ekmekçi, F. G., \& Ivanova, P. P. (2008). Divergence with gene flow 
between Ponto-Caspian refugia in an anadromous cyprinid Rutilus frisii revealed by multiple gene phylogeography. Molecular Ecology, 17(4), 1076-1088. https://doi.org/10.1111/j.1365-294X.2007.03638.x

Kottelat, M., \& Freyhof, J. (2007). Handbook of European freshwater fishes. Kottelat, Cornol and Freyhof.

Krieg, F., Triantafyllidis, A., \& Guyomard, R. (2000). Mitochondrial DNA variation in European populations of Silurus glanis. Journal of Fish Biology, 56(3), 713-724. https://doi.org/10.1006/jfbi.1999.1186

Kumar, G., Kunal, S. P., Menezes, M. R., \& Kocour, M. (2014). Genetic divergence between Auxis thazard and A. rochei based on PCR-RFLP analysis of mtDNA D-loop region. Turkish Journal of Fisheries and Aquatic Sciences, 14(2), 539-546. https://doi.org/10.4194/1303-2712-v14_2_25

Kumar, G., Kunal, S. W., \& Menezes, M. R. (2012). Genetic stock structure of frigate tuna (Auxis thazard) along Indian coast based on PCR-RFLP analyses of mtDNA DLoop region. Turkish Journal of Fisheries and Aquatic Sciences, 12(4), 893-903.

Kumar, S., Stecher, G., Li, M., Knyaz, C., \& Tamura, K. (2018). MEGAX: Molecular evolutionary genetics analysis across computing platforms. Molecular Biology and Evolution, 35(6), 1547-1549.

https://doi.org/10.1093/molbev/msy096

Kuru, M. (1975). Dicle-Fırat, Kura-Aras, Van Gölü ve Karadeniz Havzası tatlı sularında yaşayan balıkların (Pisces) sistematik ve zoocoğrafik yönden incelenmesi. Atatürk Üniversitesi, Erzurum.

Leigh, J. W., \& Bryant, D. (2015). POPART: Full-feature software for haplotype network construction. Methods in Ecology and Evolution, 6(9), 1110-1116. https://doi.org/10.1111/2041-210X.12410

Librado, P., \& Rozas, J. (2009). DnaSP v5: A software for comprehensive analysis of DNA polymorphism data. Bioinformatics, 25(11), https://doi.org/10.1093/bioinformatics/btp187

Linhart, O., Štěch, L., Švarc, J., Rodina, M., Audebert, J. P., Grecu, J., \& Billard, R. (2002). The culture of the European catfish, Silurus glanis, in the Czech Republic and in France. Aquatic Living Resources, 15(2), 139-144. https://doi.org/10.1016/S0990-7440(02)01153-1

Muscalu, R., Muscalu, C., Nagy, M., Bura, M., \& Szelei, Z. T. (2010). Studies on wels catfish (Silurus glanis) development during cold season as an auxiliary species in sturgeon recirculated aquaculture systems. $A A C L$ Bioflux, 3(5), 362-366.

Nwafili, S. A., \& Gao, T. X. (2016). Genetic diversity in the mtDNA control region and population structure of Chrysichthys nigrodigitatus from selected Nigerian rivers: Implications for conservation and aquaculture. Archives of Polish Fisheries, 24(2), 85-97. https://doi.org/10.1515/aopf-2016-0010

Paixão, R. V., Ribolli, J., \& Zaniboni-Filho, E. (2018). Genetic variation of the endangered neotropical catfish Steindachneridion scriptum (Siluriformes: Pimelodidae). Frontiers in Genetics, 9(FEB). https://doi.org/10.3389/fgene.2018.00048

Palm, S., Vinterstare, J., Nathanson, J. E., Triantafyllidis, A., \& Petersson, E. (2019). Reduced genetic diversity and low effective size in peripheral northern European catfish Silurus glanis populations. Journal of Fish Biology, 95(6), 1407-1421. https://doi.org/10.1111/jfb.14152

Parmaksiz, A. (2020). Population genetic diversity of yellow barbell (Carasobarbus luteus) from Kueik, euphrates and tigris rivers based on mitochondrial DNA D-loop sequences. Turkish Journal of Fisheries and Aquatic Sciences, 20(1), 79-86. https://doi.org/10.4194/13032712-v20_1_08

Parmaksiz, A., \& Eksi, E. (2017). Genetic diversity of the cyprinid fish Capoeta trutta (Heckel, 1843) populations from Euphrates and Tigris rivers in Turkey based on mtDNA COI sequences. Indian Journal of Fisheries, 64(1), 18-22. https://doi.org/10.21077/ijf.2017.64.1.62396-03

Phadphon, P., Amontailak, T., Kotchantuek, N., Srithawong, S., Kutanan, W., \& Suwannapoom, C. (2019). Genetic Diversity of the Endangered Mekong Giant Catfish, Striped Catfish, and Their Hybrids From Thailand. Tropical Conservation Science, 12, 1-9. https://doi.org/10.1177/1940082919869487

Posada, D. (2008). jModelTest: Phylogenetic model averaging. Molecular Biology and Evolution, 25(7), 1253-1256. https://doi.org/10.1093/molbev/msn083

Ramos-Onsins, S. E., \& Rozas, J. (2002). Statistical properties of new neutrality tests against population growth. Molecular Biology and Evolution, 19(12), 2092-2100. https://doi.org/10.1093/oxfordjournals.molbev.a00403 4

Ray, N., Currat, M., \& Excoffier, L. (2003). Intra-deme molecular diversity in spatially expanding populations. Molecular Biology and Evolution, 20(1), 76-86. https://doi.org/10.1093/molbev/msg009

Republic of Turkey Ministry of Agriculture and Forestry, Mediterranean Fisheries Research, Production and Training Institute (2019). News. Https://Arastirma.Tarimorman.Gov.Tr/Akdenizsuurunle ri/News/132/European-Catfish-_silurus-Glanis_-WereProduced-In-Our-Institute-Within-The-Period-Of-2019\#.

Rogers, A. R., \& Harpending, H. (1992). Population growth makes waves in the distribution of pairwise genetic differences. Molecular Biology and Evolution, 9, 552569.

https://doi.org/10.1093/oxfordjournals.molbev.a04072 7

Ronquist, F., Teslenko, M., Van Der Mark, P., Ayres, D. L., Darling, A., Höhna, S., Larget, B., Liu, L., Suchard, M. A., \& Huelsenbeck, J. P. (2012). Mrbayes 3.2: Efficient bayesian phylogenetic inference and model choice across a large model space. Systematic Biology, 61(3), 539-542. https://doi.org/10.1093/sysbio/sys029

Saygı, H., \& Güleç, F. (2019). Yayın Balığı (Silurus glanis Linnaeus, 1758) Tam Kontrollü Üretimi ve Cinsiyet Kontrolü. Turkish Journal of Agriculture - Food Science and Technology, 7(6), 913. https://doi.org/10.24925/turjaf.v7i6.913-918.2528

Sullivan, J. P., Lundberg, J. G., \& Hardman, M. (2006). A phylogenetic analysis of the major groups of catfishes (Teleostei: Siluriformes) using rag1 and rag2 nuclear gene sequences. Molecular Phylogenetics and Evolution, 41(3), 636-662. https://doi.org/10.1016/j.ympev.2006.05.044

Tajima, F. (1989). Statistical method for testing the neutral mutation hypothesis by DNA polymorphism. Genetics, 123(3), 585-595.

Thompson, J. D., Higgins, D. G., \& Gibson, T. J. (1994). CLUSTAL $\mathrm{W}$ : Improving the sensitivity of progressive multiple sequence alignment through sequence weighting, position-specific gap penalties and weight matrix choice. Nucleic Acids Research, 22(22), 4673-4680. https://doi.org/10.1093/nar/22.22.4673 
Triantafyllidis, A., Abatzopoulos, T. J., \& Economidis, P. S. (1999). Genetic differentiation and phylogenetic relationships among Greek Silurus glanis and Silurus aristotelis (Pisces, Siluridae) populations, assessed by PCR-RFLP analysis of mitochondrial DNA segments. Heredity, 82(5), 503-509.

https://doi.org/10.1038/sj.hdy. 6885140

Triantafyllidis, A., Krieg, F., Cottin, C., Abatzopoulos, T. J., Triantaphyllidis, C., \& Guyomard, R. (2002). Genetic structure and phylogeography of European catfish (Silurus glanis) populations. Molecular Ecology, 11(6), 1039-1055.

https://doi.org/10.1046/j.1365-294X.2002.01501.x

Triantafyllidis, A., Leonardos, I., Bista, I., Kyriazis, I. D., Stoumboudi, M. T., Kappas, I., Amat, F., \& Abatzopoulos, T. J. (2007). Phylogeography and genetic structure of the Mediterranean killifish Aphanius fasciatus (Cyprinodontidae). Marine Biology, 152(5), 1159-1167. https://doi.org/10.1007/s00227-007-0760-7

Triantafyllidis, A., Ozouf-Costaz, C., Rab, P., Suciu, R., \& Karakousis, Y. (1999). Allozyme variation in European silurid catfishes, Silurus glanis and Silurus aristotelis. Biochemical Systematics and Ecology, 27(5), 487-498. https://doi.org/10.1016/S0305-1978(98)00114-8

Vittas, S., Drosopoulou, E., Kappas, I., Pantzartzi, C. N., \& Scouras, Z. G. (2011). The mitochondrial genome of the
European catfish Silurus glanis (Siluriformes, Siluridae). Journal of Biological Research, 15, 25-35.

Xiao, Y., Zhang, Y., Gao, T., Yanagimoto, T., Yabe, M., \& Sakurai, $Y$. (2009). Genetic diversity in the mtDNA control region and population structure in the small yellow croaker Larimichthys polyactis. Environmental Biology of Fishes, 85(4), 303-314. https://doi.org/10.1007/s10641-0099497-0

Xue, Z., Zhang, Y., Sun, H., \& Wang, W. (2020). Comparative analysis on mitochondrial control region dna diversity of three far eastern catfish (Silurus asotus) populations. Turkish Journal of Fisheries and Aquatic Sciences, 20(7), 549-557. https://doi.org/10.4194/1303-2712-v20_7_05

Zhong, L., Song, C., Wang, M., Chen, Y., Qin, Q., Pan, J., \& Chen, X. (2013). Genetic diversity and population structure of yellow catfish Pelteobagrus fulvidraco from five lakes in the middle and lower reaches of the Yangtze River, China, based on mitochondrial DNA control region. Mitochondrial DNA, 24(5), 552-558. https://doi.org/10.3109/19401736.2013.770491

Zwickl, D. J. (2006). Genetic algorithm approaches for the phylogenetic analysis of large biological sequence datasets under the maximum likelihood criterion [University of Texas at Austin, Austin.]. In Ph.D. Dissertation.

https://doi.org/(http://www.zo.utexas.edu/faculty/anti sense/garli/Garli.html) 